\title{
Impact of brine, lye solution and water on sensory attributes of olive fruits
}

\author{
Ali Muhammad*, Muhammad Ayub, Yasser Durrani, Ihsan Mabood \\ Qazi, Syed Awais Ali, Majid Suhail Hashmi and Saifullah \\ Department of Food Science and Technology, The University of Agriculture Peshawar Pakistan \\ *Corresponding author's email: alizypher@aup.edu.pk \\ Citation
}

Ali Muhammad, Muhammad Ayub, Yasser Durrani, Ihsan Mabood Qazi, Syed Awais Ali, Majid Suhail Hashmi and Saifullah. Impact of brine, lye solution and water on sensory attributes of olive fruits. Pure and Applied Biology.

Vol. 7, Issue 1, pp20-25. http://dx.doi.org/10.19045/bspab.2018.70003

\begin{tabular}{llll}
\hline \hline Received: 29/09/2017 & Revised: 20/12/2017 & Accepted: 21/12/2017 & Online First: 01/01/2018 \\
\hline \hline
\end{tabular}

\section{Abstract}

Olive is the only fruit of Oleaceae family which bear edible fruit. The fruit is unable to eat fresh because it contains a bitter glucoside. Olive fruit are only processed for oil extraction but due to its bitter taste very little amount of fruits can be processed to preserve for human consumption. To reduce the bitter taste of olive fruit and made them edible, the olive fruits were treated by lye, water and brine solutions. Samples were analyzed for color, flavor, taste and overall acceptability. Results showed that initially mean score value for color of olive fruit treated with water was recorded as 9.00 which gradually decreased to 7.33 , while for flavor mean value of judges was 2.67 which increased to 6.67 , similarly mean value for taste was 1.67 which gradually increased to 6.00 during 4 weeks treatments. Similarly for color of brine treated olives fruits initially the mean score value of judges was 9.00 which decreased to 5.33 , for flavor the score was recorded as 2.33 which increased to 6.00 and for taste the mean score value was recorded as 2.00 which increased to 5.67. Mean score values for lye treated olive fruit decreased from 9.00 to 5.33while flavor and taste decreased from 2.33 to 6.00 and 2.00 to5.67 respectively during four weeks of treatment. Organoleptic evaluation of treated olive fruits showed that fruit with water treatment was found best followed by fruits which were treated with brine solution.

Keywords: Color; Flavor; Lye solution; Olive fruit; Over all acceptability; Taste brine; Water

\section{Introduction}

Kalamata fruits are variety of the olive tree which belongs to Oleacea family cannot be eaten when picked in fresh form because it contains glucosides which produce bitter taste. The bitterness can be reduced by salt or lye treatment or it can present whole fruit as a food. Oil can also be extracted from olive fruit. In California, bitterness of the olive fruit removed before processing [1,2].

During maturation the carbohydrates content of olive fruits such as minitol, glucose and saccharoses decreased from 3.50 to 6.00 . While olive fruit contains $1.5-2.2 \%$ protein content by fruit weight basis. Texture of the flesh mostly affect by cement like substance called pectic acid which hydrolysed during processing enzyme pectinolytic and affect the fruit texture become softer. Olive fruit contains high levels of free fatty acids, succinic, malic acid and citric acids as in the form of organic acids [3].

Olives enhance consumers' perception of quality and production of healthier products, 
can be observed worldwide to fulfill their nutritious thirst. Olives contains $45-55 \%$ water, oil 13-28\%, 1.5-2.0\% N-compound, $18-40 \%$ Carbon containing compound, Ash in the amount of $1-2 \%$ and $5-8 \%$ fibre respectively [4].

Olive fruit have antioxidant and antimicrobial properties due to the presence of tocopherols and phenolic compounds, which act as protecting agent against disease causing microorganisms especially from arthrosclerosis, cardiovascular and cancer [5].

The debittering process is a treatment of the olives with sodium hydroxide solutions with concentrations ranging between $1.5 \%$ and $3.0 \%$. The principal objectives of this operation are to eliminate the bitter taste conferred by the glycoside oleuropein [6] and to increase the permeability of the fruits in order to facilitate the exit of different nutrients to be used by lactic bacteria during the subsequent fermentation process [7]. The lye treatment gives rise to complex chemical and physical changes in the fruits, and its extent also affects the subsequent diffusion of salt and the progress of the lactic fermentation $[8,9]$. The skin is a natural barrier to the penetration of $\mathrm{NaOH}$ and other solutes to the interior of the olives. Its permeation is a function of the treatment conditions such as lye concentration and temperature, and olive variety and maturity [10]. Drusas et al. [11] quantified the diffusion of sodium chloride into green olives placed in brines of various concentrations. They studied untreated olives and olives pretreated with lye at $1.8 \%$ for $6 \mathrm{~h}$ and calculated salt effective diffusion coefficients assuming a hollow sphere geometry and negligible external resistance to mass transfer. They measured the absorption of salt from changes in brine concentration.

During the treatment with lye, sugars and other nutrients are lost into the solution. These losses also continue during the rinsing of the olives [12] and the subsequent curing in brine. Due to the diffusion process, the brine becomes an appropriate growth media for microorganisms responsible of the lactic fermentation $[6,13]$ that will provide the acidity necessary for the stability and preservation of the olives [14]. The necessary nutrients come from within the olives and their concentration in the brine is determined by the extent of the debittering process.

The edibility of olive fruits can be achieve by curing of olive fruit, brining of the Spanish green olive, while Greek black olive can be cured in salt solution or may be processed by other treatment [15]. Adverse weather conditions, different stage of maturity and seasonal variation can affect composition of olive fruit and also quantity of the fruit [16]. Due to bitter glycosides olive fruits are unable to eat. The treatments were done in order to minimize the bitterness level of olive fruits. Thus enhancing the eat-ability of olive fruits and the consumers' perceptions regarding the acceptability of these fruits.

\section{Materials and methods}

Olive's fruits were collected from research station CCRI which is situated at Persabak, district Nowshera. Sorting of the fruits were carried out in the Laboratory to remove the spoiled fruits. After pre-treatment of the fruits, pulper machine was to extract the edible portion and plastic bottles, jars were used for the preservation of pulp for further study. Proposed plan has given in table 1 .

Table 1. Treatment of olive fruit for reducing its bitterness

\begin{tabular}{|c|c|c|}
\hline Water Treatments & Brine Treatments & Lye Treatment \\
\hline Week- $1^{\text {st }}$ & Week- $1^{\text {st }}$ & Week-1 ${ }^{\text {st }}$ \\
\hline Week- $2^{\text {nd }}$ & Week-2 ${ }^{\text {nd }}$ & Week-2 ${ }^{\text {nd }}$ \\
\hline Week- $3^{\text {rd }}$ & Week- $3^{\text {rd }}$ & Week- $3^{\text {rd }}$ \\
\hline Week- $4^{\text {th }}$ & Week- $4^{\text {th }}$ & Week- $4^{\text {th }}$ \\
\hline
\end{tabular}




\section{Organoleptic evaluation}

Treatments were subjected to trained judges for organoleptic evaluation (taste, color, flavor, overall acceptability) using Hedonic scale having 1-9 points [17].

\section{Statistical analysis}

Statistical evaluation of the data was done by Statistix 1.8 registered software for statistics, graphs were made by origin software, standard deviation and means were separated by LSD as described by [18].

\section{Results and discussion}

Initially mean score value of olive fruit treated with water on $1^{\text {st }}$ week was 9.00 a decreasing trend occurs on $2^{\text {nd }}$ week from 9.00 to $8.00,7.67$ and 7.33 , while increasing trend occurs on $2 \mathrm{n}$ week for flavor from 2.67 to $4.67,6.67$ and 6.67 . Similarly mean score value for taste increased from 1.67 to 3.67 , 4.00 and 6.00 during 4 weeks of treatments process (Table 2 \& Figure 1). Durrani et al. [19] studied sensory characteristic of mango pulp and concluded that color of pulp decreased during 90 day of storage life. At room temperature by adding chemical additive the shelflife of mango pulp may increase to one year. Adding sodium benzoate along with combination of metabisulphite retained the sensory properties of mango pulp [20].

To make a decision regarding the purchasing of a food, the most important criteria are the appearance. For any product to judge its quality during manufacturing, marketing, storage and finally for end user appearance is the primary means of that product $[21,22]$.

Similarly in another study mango pulp with preservatives were analyzed for sensory parameters for a storage time of 270 days and the results were satisfactory. During evaluation of the product was analyzed for firmness, texture, shape, color and taste and retained maximum appearance $[23,24]$.

Table 2. Mean scores of judges of overall acceptability for treated olive fruit after dipping on weekly basis

\begin{tabular}{|c|c|c|c|c|}
\hline Residues & Treatments & Color & Flavor & Taste \\
\hline \multirow{4}{*}{ Water } & Week $1^{\text {st }}$ & $9.00 \mathrm{a} \pm 0.01$ & $2.67 \mathrm{a} \pm 0.02$ & $1.67 \mathrm{a} \pm 0.02$ \\
\hline & Week $2^{\text {nd }}$ & $8.00 \mathrm{~b} \pm 0.01$ & $4.67 b \pm 0.01$ & $3.67 b \pm 0.04$ \\
\hline & Week $3^{\text {rd }}$ & $7.67 b c \pm 0.03$ & $6.67 c \pm 0.00$ & $4.00 b c \pm 0.02$ \\
\hline & Week $4^{\text {th }}$ & $7.33 \mathrm{~cd} \pm 0.02$ & $6.67 c \pm 0.04$ & $6.00 \mathrm{~d} \pm 0.05$ \\
\hline \multirow{4}{*}{ Brine } & Week $1^{\text {st }}$ & $9.00 \mathrm{a} \pm 0.01$ & $2.67 \mathrm{a} \pm 0.03$ & $1.33 \mathrm{a} \pm 0.01$ \\
\hline & Week $2^{\text {nd }}$ & $8.33 \mathrm{ab} \pm 0.01$ & $4.33 b \pm 0.04$ & $4.67 b \pm 0.05$ \\
\hline & Week $3^{\text {rd }}$ & $7.67 b c \pm 0.00$ & $5.33 c \pm 0.02$ & $5.33 b c \pm 0.02$ \\
\hline & Week $4^{\text {th }}$ & $6.67 d \pm 0.01$ & $7.00 \mathrm{~d} \pm 0.01$ & $5.67 d \pm 0.01$ \\
\hline \multirow{4}{*}{ Lye } & Week $1^{\text {st }}$ & $9.00 \mathrm{a} \pm 0.02$ & $2.33 \mathrm{a} \pm 0.01$ & $2.00 \mathrm{a} \pm 0.03$ \\
\hline & Week $2^{\text {nd }}$ & $8.00 b \pm 0.01$ & $5.33 b \pm 0.03$ & $3.00 \mathrm{~b} \pm 0.02$ \\
\hline & Week $3^{\text {rd }}$ & $7.33 c \pm 0.01$ & $5.67 b c \pm 0.02$ & $4.67 c \pm 0.01$ \\
\hline & Week $4^{\text {th }}$ & $5.33 d \pm 0.03$ & $6.00 \mathrm{~cd} \pm 0.03$ & $5.67 b c \pm 0.04$ \\
\hline
\end{tabular}

Similarly for color of brine treated olive fruit mean score value decreased from 9.00 to $8.33,7.67$ and 6.67 while mean score value of flavor and taste increased from 2.67 to 4.33, 5.33 and 7.00. Similarly mean score value for taste increased from 1.33 to 4.67 , 5.33 and 5.67 during a total duration of 4 weeks. Table 2 and figure 2 findings were agreed with the concluded results of [19] who studied a decreasing trend in flavor of apple fruit pulp during storage life of 90 days. Potassium metabisulphite affect the flavor of fruits, increase the shelflife but also act as a bleaching agent and decrease the natural color of fruit 
Samples which treated with lye solution were taken for organoleptic evaluation. Initially judges score value for olive fruit treated with lye solution on $1^{\text {st }}$ week was $9.00,2^{\text {nd }}$ week (8.00), $3^{\text {rd }}$ week (7.33) and $4^{\text {th }}$ week (5.33) respectively, while in flavor increasing trend was observed, initially on $1^{\text {st }}$ week the mean score value was 2.33 which increased from 2.33 to $5.33,5.67$ and 6.00 respectively. Similarly mean score value for taste was 2.00 on $1^{\text {st }}$ week which increased to 3.00 on $2^{\text {nd }}$ week, 4.67 on $3^{\text {rd }}$ week and 5.67 on $4^{\text {th }}$ week of treatments (Table $2 \&$ Figure 3 ).

These results are corresponding with $[25,26]$ who concluded a decreasing behavior in color and flavor of mango and Banky apple at $\mathrm{RH} 70-75 \%$ and temperature 32 to $36^{\circ} \mathrm{C}$. [19] Investigated that the preservation effect of potassium metabisulphite with combination of potassium sorbate at $0.05 \%$ and addition of ascorbic acid (0.1\%) on mango pulp which showed best result for sensory studies. Chemical preservatives have beaching characteristics which affect the natural yellow color of the fruit. Change in percent acidity and $\mathrm{pH}$ also have effect on sensory quality of the fruit during storage. Hedonic scale start from 9 (highest score) and end at 1 which shows low quality $[27,28]$.

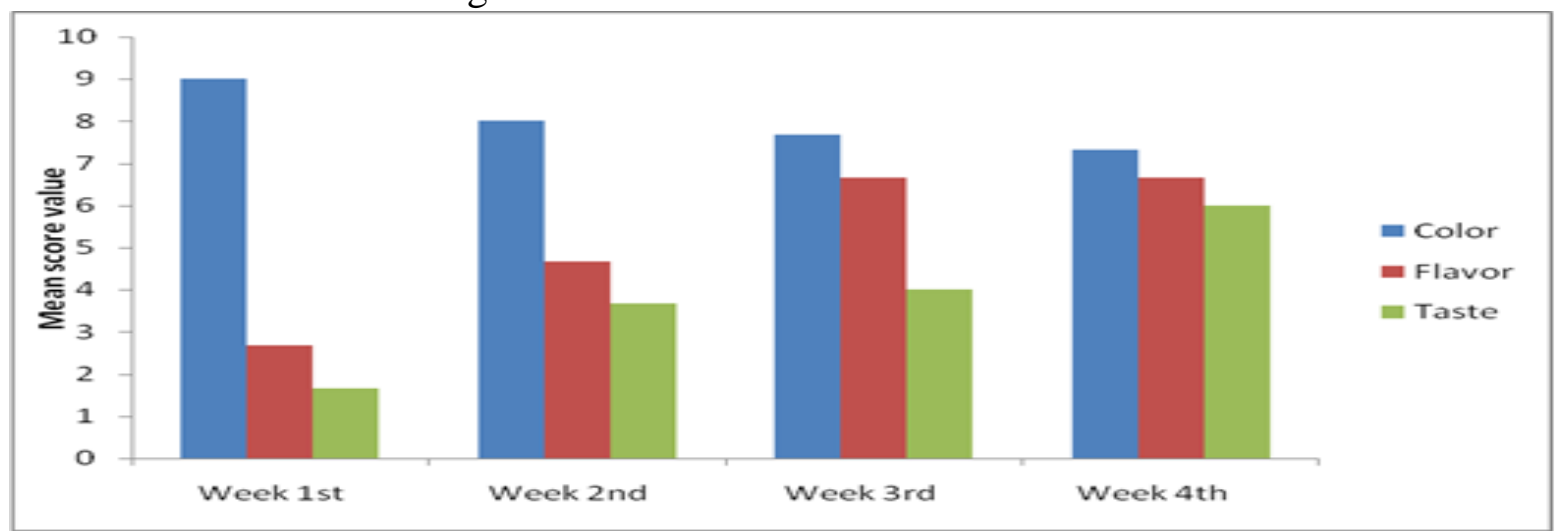

Figure 1. Overall acceptability of water treated olive fruit

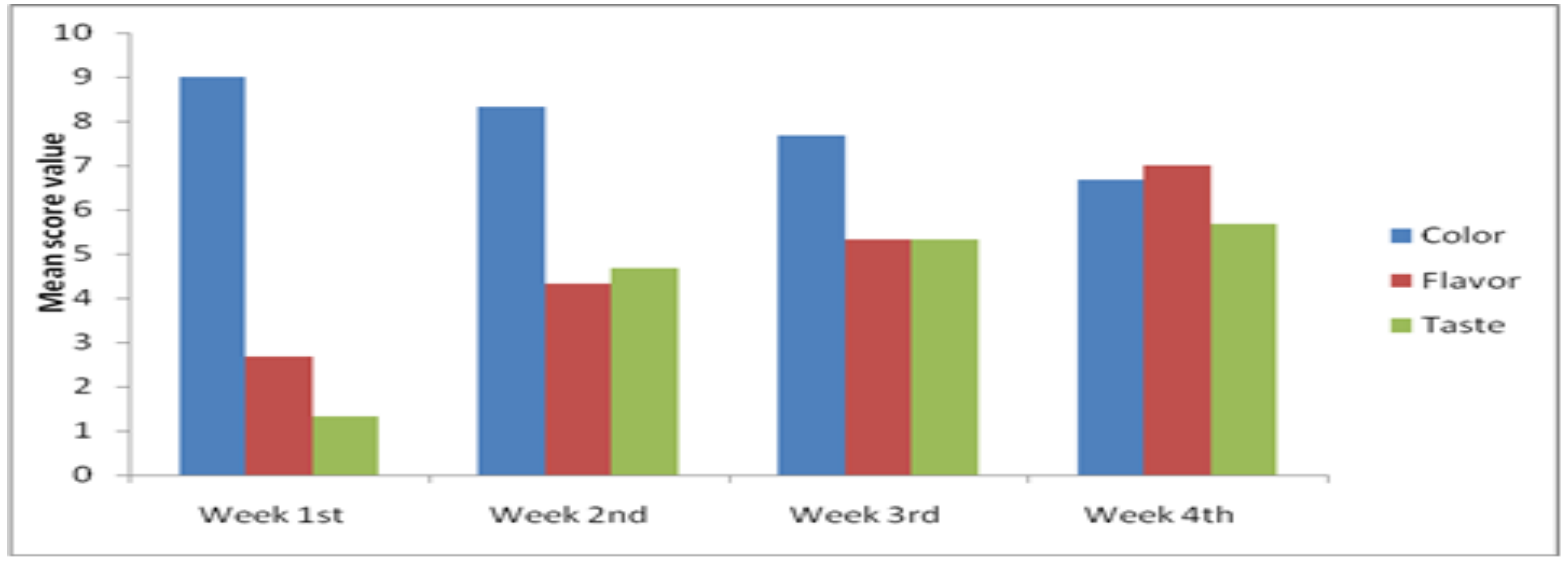

Figure 2. Overall acceptability of brine treated olive fruit 


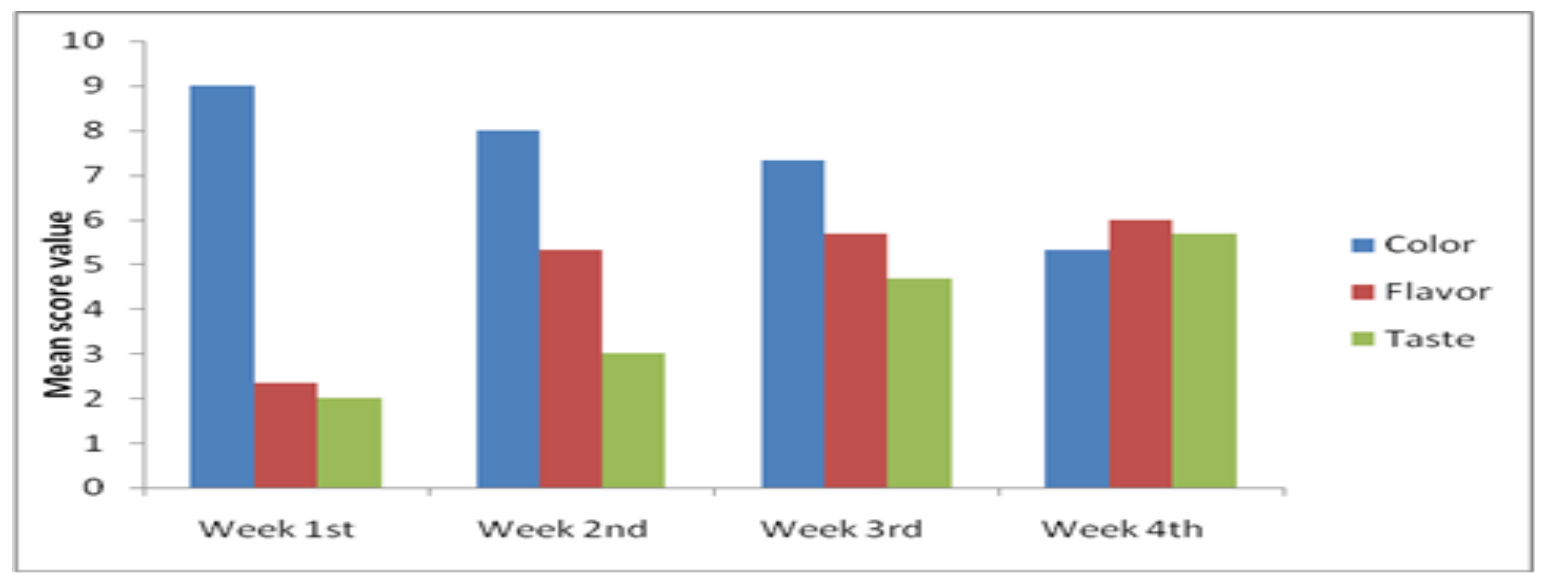

Figure 3. Overall acceptability of lye treated olive fruit

\section{Conclusion}

For reduction of bitterness brine, lye and water treatments were made. Results showed that best result was obtained by olive fruits treated with water having mean score value for color (7.33), flavor (6.67) and Taste (6.00) followed by olive fruits which were treated with brine having mean score value for color (6.67), flavor (7.00) and Taste (5.67) respectively during treatment period of time.

\section{Authors' contributions}

Conceived and designed the experiments:, A Muhammad \& M Ayub, Performed the experiments: A Muhammad, Analyzed the data:, Y Durrani \& IM Qazi \& Saifullah, Contributed materials/ analysis/tools: SA Ali \& MS Hashmi, Wrote the paper: A Muhammad, M Ayub, Y Durrani, IM Qazi, SA Ali, MS Hashmi \& Saifullah.

\section{Acknowledgment}

We thanks to CCRI Persabak for the supply of olive fruit varieties and The, University of Agriculture Peshawar for providing laboratory facilities and financial support.

\section{References}

1. Dubur-Jarrige MA (2001). Les Origines de la culture de l' olivier en Méditerranée: le point sur les découvertes paléobotaniques et leurs interprétations, in Actes des léres Rencontres Internationales de 1' olivier (19 et 20 Octobre 2000) L' olivier dans l' espace et dans le temps. Institute du monde de l' olivier, Nyons, 10-22.
2. Mc-Eachern GR \& Larry AS (1997). Growing Olives in Texas Gardens. Extension Horticulturists Texas A \& M University College Station, Texas 77843-2134.

3. Marsilio V (2006). The use of LAB starters during table olive fermentation. In: proceedings of the 2nd International Seminar Olivebioteq, 5-10 November 2006, Marsala-Mazara del Vallo, Italy, Seminars and invited lectures 221-233.

4. Kastorini CM, Milionis HJ, Goudevenos JA \& Panagiotakos DB (2010). Mediterranean diet and coronary heart disease: is obesity a link, Asystematic review. Nutrition, Metabolism, \& Cardiovascular Diseases 20: 536-551.

5. Armstrong N, Paganga G, Brunev E \& Miller $N$ (1997). Reference values for $\alpha$-tocopherol and $\beta$-carotene in the Whitehall II study. Free Radical Research 27(1): 207-219.

6. Marsilio V, Lanza B (1998). Characterization of an oleuropein degrading strain of Lactobacillus plantarum. Combined effects of compounds present in olive fermenting brines (phenols, glucose and $\mathrm{NaCl}$ ) on bacterial activity. J Sci Food Agric 76(1): 520-524.

7. Papamichael \& Balatsouras (1988). Utilization of modified spent lye as cover brine of Conservolea olives subjected to fermentation as green of Spanish style. Grasas $y$ Aceites 39(1): 17-21.

8. Rodriguez de la Borbolla JM, and Rejano L (1979). Sobre la preparacion e la aceituna estilo sevillano. La fermentation I. Grasas y Aceites 30(1): 175-185. 
9. Sciancalepore V, and Longone V (1984). Polyphenol oxidase activity and browning in green olives. J Agric Food Chem 32(1): 320321.

10. Barranco D (1997). In: D. Barranco, R. Fernández-Escobar, and L. Rallo (eds.). El cultivo del olivo. Mundiprensa y Junta de Andalucía, Madrid, Spain. Variedades y patrones 9-80.

11. Drusas A, Vagenas GK \& Saravacos GD (1988). Diffusion of sodium chloride in green olives. J Food Eng 7(1): 211-222.

12. Fernández-Diez MJ (1985). Biotecnología de la aceituna de mesa. Publicaciones CSIC. Sevilla, Madrid.

13. Bobillo M, Marshall VM (1991). Effect of salt and culture aeration on lactate and acetate production by Lactobacillus plantarum. Food Microbiol 8: 153-160.

14. Marsilio V, Di Giovacchino L, Lombardo N, Briccoli-Bati C (1990). First observations on the disposal effects of olive mills vegetation waters on cultivated soil. Issue Series Title: Acta.Hort 286(1): 493-498.

15. Sabatini N, Perri E and Marsilio V (2009). An investigation on molecular partition of aroma compounds in fruit matrix and brine medium of fermented table olives. Innovative Food Science and Emerging Technologies 10: 621-626.

16. Romero C, Brenes M, Yousfi K, Garcia P, Garcia A and Garrido A (2004). Effect of cultivar and processing method on the contents of polyphenols in table olives. $J$ Agric Food Chem 52: 479-484.

17. Larmond E (1977). Laboratory Methods for Sensory Evaluation of Foods. Research Branch, Canada. Deptt of Agri Pub No. 1637.

18. Steel RGD, Torrie JH \& Dickey DA (1997). Principles and procedures of statistics-a biometrical approach ( ${ }^{\text {rd }}$ edition). McGraw Hill Book Co. Inc., New York, USA.

19. Durrani Y, Zeb A, Ayub M, Ullah W \& Muhammad A (2011). Sensory evaluation of mango (chaunsa) pulp preserved with addition of selected chemical preservatives and antioxidant during storage. Sarhad J Agric 27(3): 471-475.

20. Sonia S, Sogi DS \& Bawa AS (2003). Shelflife studies on chemically preserved sand pear (Pyrus pyrifolia cv Patharnakh) pulp. J Food Sci Tech 40(2): 230-232.

21. Kays SJ (1999). Pre-arrest conditions affecting appearance. Postharvest Bio and Tec 15: 233-247.

22. Kays SJ (1991).Post-harvest physiology of perishable plant products; Vas Nostrand Rein Hold Book, AVI Publishing Co, pp. 149-316.

23. Costa C, Antonucci F, Pallottino F, Aguzzi J, Sun DW \& Menesatti P (2011). Shape analysis of agricultural products: a review of recent research advances and potential application to computer vision. Food Bioprocess Technology 4(5): 673-692.

24. Hussain S, Rehman S, Randhawa MA \& Iqbal M (2003). Studies on Physicochemical, microbiological and sensory evaluation of mango pulp storage with chemical preservatives. J Res Sci BZ Uni Multan Pak 14: 01-09.

25. Hayat I, Tariq M \& Habib AR (2005). Effect of Coating and Wrapping materials on the shelf life of apple (Malus domestica cv. Borkh). Internet Journal of Food Safety (5): 24-34.

26. Raje L, Sherlekar S, Ramakrishnan K, Malshe VC \& Subbulakshmi G (1997). Postharvest preservation of mangoes by controlled chemical release agents and absorbent. Acta Hort 455: 622-628.

27. Selvamuthukumaran M, Khanum F \& Bawa AS (2007). Development of sea buckthorn mixed fruit jelly. Int J Food Sci Tech 42: 403-410.

28. Chakraborty SK, Kumbhar BK, Shalini C \& Pravesh Y (2011). Influence of processing parameters on textural characteristics and overall acceptability of millet enriched biscuits using response surface methodology. J Food Sci Technol 48(2): 167-174. 